\title{
ANALISIS DAMPAK PELAKSANAAN PROGRAM AGRIBISNIS PETERNAKAN SAPI POTONG TERHADAP PEMBERDAYAAN MASYARAKAT PEDESAAN
}

\author{
Zulkifli \\ (Staff Ahli Pimpinan DPRD Kota Semarang) \\ zulkifli737@yahoo.com
}

\begin{abstract}
Sragen regency is one of the districts that most of the population is farmers, this research sees the impact of livestock agribusiness programs on empowerment of rural communities. The results showed that the formation of beef cattle group as much as $72.55 \%$ influenced by agribusiness programs and 27.45 livestock \% formed before any program. The number of livestock cattle ownership during this activity increased by an average of $50.71 \%$, ie 1.78 birds. the group receiving further assistance experienced a decrease of $72.55 \%$ ie 37 farmers. The level of empowerment of farmers in accessing capital from the government is 58.82\%, from Bank BRI, $41.18 \%$ from Central Java Bank, 7.84\% from Jamsostek and $7.84 \%$ from Balitbang 3.92\%. Empowerment in accessing Market information, as much as $52.95 \%$ accessing from beauty and $47.05 \%$ accessing from the cattle market. The drug information as a whole is accessible from the government. Empowerment of farmers in accessing technology as a whole access from the government. Farmer participation through intensity level of group meeting, 80,39\% meeting once a month, 5.88\% 2 times in one month, 7.84\% 1 time in 2 months and 5.88\% 1 time in 3 months. The activities in the meeting consisted of group program evaluation, decision making, group programming and group members' gathering. A total of $47.06 \%$ of farmers use communal cages in groups and 52.94\% using individual cages.
\end{abstract}

Keywords: empowerment, agribusiness, society, rural.

Abstrak. Kabupaten Sragensalah satu kabupaten yang sebagian besar penduduknya adalah petani, penelitian ini melihat dampak program agribisnis peternakan terhadap pemberdayaan masyakarat pedesaan..Hasil penelitian menunjukkan bahwa pembentukan kelompok ternak sapi potong sebanyak $72,55 \%$ di pengaruhi oleh program agribisnis peternakan dan 27,45\% dibentuk sebelum ada program. Jumlah kepemilikan ternak sapi potong dari selama kegiatan ini meningkat rata-rata 50,71\% yaitu sebesar 1,78 ekor. kelompok yang mendapatkan bantuan lanjutan mengalami penurunan $72,55 \%$ yaitu sebesar 37 peternak. Tingkat kemampuan peternak dalam mengakses modal dari pemerintah sebanyak 58,82\%, dari Bank BRI, 41,18\% dari Bank Jateng, 7,84\% dari Jamsostek dan 7,84\% dari Balitbang 3,92\%. Kemampuan peternak dalam mengakses Informasi pasar, sebanyak 52,95\% mengakses dari blantik dan 47,05\% mengakses dari pasar sapi. Informasi obat secara keseluruhan mengakses dari pemerintah. Kemampuan peternak dalam mengakses teknologi secara keseluruhan mengakses dari pemerintah. Partisipasi peternak melalui tingkat intensitas pertemuan anggota kelompok, sebanyak 80,39\% pertemuan 1 kali dalam satu bulan, 5,88\% 2 kali dalam satu bulan, 7,84\% 1 kali dalam 2 bulan dan 5,88\% 1 kali dalam 3 bulan. Kegiatan dalam pertemuan terdiri dari evaluasi program kelompok, pengambilan keputusan, menyusun program kelompok dan arisan anggota kelompok. Sebanyak 47,06\% peternak menggunakan kandang komunal secara berkelompok dan 52,94\% menggunakan kandang individu.

Kata Kunci : pemberdayaan, agribisnis, masyarakat, pedesaan. 


\section{PENDAHULUAN}

\section{Latar Belakang}

Indonesia merupakan salah satu negara berkembang di dunia yang masih menghadapi permasalahan baik di bidang ekonomi, sosial, hukum dan politik. Beberapa masalah yang belum dapat diselesaikan oleh pemerintah adalah masalah kemiskinan dan pengangguran yang diakibatkan oleh bergesernya pembangunan sektor pertanian atau peternakan ke sektor industri.

Data Badan Pusat Statistik Nasional menunjukan jumlah penduduk miskin dari tahun ke tahun, baik di kota maupun di desa terus berfluktuatif, pada periode 2009 hingga 2013 terjadi peningkatan jumlah penduduk miskin, pada tahun 2009 berjumlah 32,53 juta jiwa menjadi 38,07 juta jiwa pada tahun 2013, sementara persentase laju pertumbuhan penduduk miskin juga mengalami fluktuasi. Periode yang sama tahun 2009 sampai 2013 terlihat bahwa jumlah penduduk miskin lebih banyak di daerah perdesaan daripada di perkotaan. Hal ini selaras dengan pernyataan Menteri Pertanian pada suatu kesempatan bahwa 70 persen masyarakat miskin Indonesia adalah petani/peternak yang berada di pedesaan.

Presiden RI Susilo Bambang Yudoyono pada tanggal 11 Juni 2005 telah mencanangkan program Revitalisasi dengan program-program utama antara lain: Program Peningkatan Ketahanan Pangan, Pengembangan Agribisnis, Peningkatan Kesejahteraan Petani serta Pengembangan Sumberdaya dan Pemantapan Pemanfaatannya baik di bidang perikanan, maupun kehutanan yang bertujuan untuk meningkatkan kesejahteraan petani dan nelayan.

Departemen Pertanian RI telah memfokuskan pada pembangunan pertanian perdesaan. Langkah yang ditempuh adalah melalui pendekatan pengembangan usaha agribisnis dan memperkuat kelembagaan pertanian di perdesaan, melalui Keputusan Menteri Pertanian (KEPMENTAN) No.16/OT.140/2/2008 tentang tim pengembangan usaha agribisnis perdesaan.

Program agribisnis pedesaan merupakan program terobosan Departemen Pertanian untuk penanggulangan kemiskinan dan penciptaan lapangan kerja, sekaligus mengurangi kesenjangan pembangunan antar wilayah pusat dan daerah serta antar sub sektor. Program agribisnis peternakan pedesan berbentuk fasilitasi bantuan modal usaha petani anggota baik petani pemilik, petani penggarap, buruh tani maupun rumah tangga tani program agribisnis memiliki tujuan antara lain: (1) Mengurangi tingkat kemiskinan dan pengangguran melalui penumbuhan dan pengembangan kegiatan usaha agribisnis di perdesaan sesuai dengan potensi wilayah, (2) Meningkatkan kemampuan pelaku usaha agribisnis, pengurus gapoktan, penyuluh dan penyelia mitra tani, (3) Memberdayakan kelembagaan petani dan ekonomi perdesaan untuk pengembangan kegiatan usaha agribisnis dan (4) Meningkatkan fungsi kelembagaan ekonomi petani menjadi jejaring atau mitra lembaga keuangan dalam rangka akses permodalan.

Penduduk Kabupaten Sragen sebanyak 248.412 jiwa dari 871.951 jiwa,bekerja sebagai petani atau peternak. Hal ini menunjukkanbahwa Kabupaten Sragen merupakan salah satu daerah yang pembangunannya difokuskan pada sektor pertanian/peternakan. Hal ini terbukti dari sektor pertanian atau peternakan mampu memberikan kontribusi terhadap total 
Produk Domestik Regional Bruto (PDRB) Kabupaten Sragen sebesar 34,92 persen, yaitu sebesar Rp. 1.448.369.280.000,00 (Satu triliun empat ratus empat puluh delapan miliar tiga ratus enam puluh sembilan juta dua ratus delapan puluh ribu rupiah), dari total PDRB sebesar Rp.4.042.561.360.000,0 (Empat triliun empat puluh dua miliar tiga ratus enam puluh ribu rupiah) pertahun (Dinas Peternakan dan Perikanan, 2013).

Program Agribisnis Peternakan Pedesaan yang berbasis rumah tangga ini sudah berjalan di Kabupaten Sragen sejak tahun 2004, program tersebut terdiri dari budidaya ternak seperti pembibitan dan penggemukan sapi potong, ternak kambing, ternak domba, ternak ayam ras potong, ternak ayam ras petelur, ternak itik, ternak jangkrik industri, ternak burung puyuh dan ternak kelinci. Pelaksanaannya pemerintah memberikan bantuan modal secara langsung dan kredit kepada kelompok ternak. Jumlah bantuan berbeda beda setiap kelompok ternak desesuaikan dengan jumlah anggota kelompok ternak dan jenis ternak yanag dipelihara.Bantuan modal yang diberikan kepada peternak sapi potong,sebagian besar pemeliharaanya dilakukan secara intensif di kandangkandang komunal secara kelompok.

Penduduk Kabupaten Sragen sebagian besar mengantungkan hidupnya di sektor pertanian atau peternakan. Sektor tersebut masih banyak mendapatkan permasalahan di antaranya banyaknya pengagguran, lemahnya keterampilan, kurangnya akses modal, akses teknologi dan informasi, sehingga sumber daya alam yang melimpah di Kabupaten Sragen tidak dikelola secara optimal oleh peternak sapi potong. Kehadiran program agribisnis peternakan pedesaan diharapkan dapat merubah kondisi tersebut ke arah yang lebih baik. Berdasarkan hal tersebut menarik untuk diteliti :

1. Seberapa besar dampak pelaksanaan program agribisnis peternakan di Kabupaten Sragen terhadap peternak sapi potong ?

2. Seberapa besar tingkat pemberdayaan peternak sapi potong dari program agribisnis peternakan di Kabupaten Sragen?

\section{Tujuan}

Berdasarkan permasalahan di atas, maka tujuan dari penelitian ini adalah :

1. Menganalisis dampak pelaksanaan program agribisnis peternakan terhadap peternak sapi potong di Kabupaten Sragen,

2. Menganalisis tingkat pemberdayaan peternak sapi potong pada program agribisnis peternakan di Kabupaten Sragen.

\section{METODELOGI}

\section{Rancangan Penelitian}

Keberlanjutan program agribisnis peternakan pedesaan sangat ditentukan pada keberhasilan pengelolaannya. Beberapa pendekatan yang dapat dilakukan untuk melihat keberhasilan program agribisnis peternakan pedesaan ini, yaitu dengan mengukur dan menilai dampak pelaksanaan program agribisnis peternakan, berupa meningkatnya jumlah kepemilikan ternak dan adanya bantuan lanjutan, kemudian tingkat pemberdayaan peternak, diukur dari tingkat kemampuan peternakdalammengakses modal, informasi dan teknologi, dan tingkat partisipasi anggota kelompok, yang diukur berdasarkan intensitas pertemuan dan kebersamaan anggota kelompok dalam mengambil keputusan, sehingga diharapkan mampu meningkatkan 
kesejahteraan peternak pedesaan dan menguatkan fungsi kelembagaan peternak.

\section{Tempat dan Waktu Penelitian}

Penelitian tentang analisis dampak pelaksanaan program agribisnis peternakan sapi potongterhadap pemberdayaan masyarakat pedesaan, di Kabupaten Sragen Provinsi Jawa Tengah, dilaksanakan di 9 kecamatan yang berada di Kabupaten Sragen Provinsi Jawa Tengah.Penelitian ini dilaksanakan padatanggal 10 Desember 2013 sampai dengan 10 Maret 2014.

\section{Metode Penelitian}

Penelitian ini menggunakan beberapa metode diantaranya yaitu metode survey, menggunakan kuesioner kepada peternak yang menerima bantuan program agribisnis peternakan sapi potong, wawancaralangsung dengan Kepala Bidang UsahaPeternakan dan Kepala Dinas Peternakan dan Perikanan Kabupaten Sragen dan observasi lapangan.

\section{Populasi dan sampling}

\subsection{Populasi}

Populasi adalah keseluruhan karakteristik atau unit hasil pengukuran yang menjadi objek penelitian atau populasi merupakan objek atau subjek yang berada pada suatu wilayah yang memenuhi syarat-syarat tertentu berkaitan dengan masalah penelitian Sarmanu (2006). Populasi dalam penelitian ini adalah 132 kelompok dengan jumlah 205 orang. yang menerima bantuan dari program agribisnis peternakan yang berada di 18 kecamatan se Kabupaten Sragen.

\subsection{Sampling}

Sampel adalah bagian dari jumlah dan karakteristik yang dimiliki oleh populasi Sarmanu (2006). Besarnya sampling yang digunakan dalam penelitian ini, ditentukan dengan menggunakan metode multistage random sampling, yaitu metode menggunakan strata, untuk menghomogenkan populasi dalam penelitian agar semua populasi mempunyai kesempatan sama untuk dipilih menjadi sampel penelitian Sarmanu (2006). Besarnya ukuran sampel yang digunakan pada penelitian ini ebanyak 51 orang responden.

\section{Jenis dan Sumber Data}

Jenis data yang digunakan yaitu :

a. Data kuantitatif adalah data yang wujudnya berupa angka-angka yang diperoleh dari hasil pengukuran persentasi dari masingmasing indikator.

b. Data kualitatif adalah data yang pada umumnya dalam bentuk pernyataan yang berhubungan dengan variabel penelitian.

Adapun Sumber data yang digunakan yaitu :

a. Data Primer adalah data yang bersumber dari hasil wawancara langsung dengan peternak dan beberapa pihak lain yang mempunyai kaitan atas indikatorindikator yang digunakan dalam penelitian ini.

b. Data sekunder adalah data yang bersumber dari instansi yang terkait dengan penelitian seperti Dinas Peternakan dan Perikanan, Badan Pusat Statistik, Badan Pembangunan Daerah dan literatur yang mendukung materi penelitian.

\section{Metode Pengumpulan Data}

a. Observasi adalah dengan melakukan kunjungan langsung dan mengamati lokasi usaha para peternak, pada program agribisnis peternakan di Kabupaten Sragen.

b. Wawancara adalah melakukan komunikasi dua arah kepada peternak dan pihak terkait dengan 
bantuan kuesioner atau daftar pertanyaan.

1. Wawancara langsung dengan peternak menggunakan kuesioner.

2. Wawancara langsung dengan pihak instansi terkait.

\section{Analisis Data}

Data yang telah diproses dari hasil penelitian ini, kemudian di analisis menggunakan analisis statistik diskriptif terdiri dari diskriptif kuantitatif dan diskriptif kualitatif. Data yang dianalisis secara kuantitaif diskriptif berupa jumlah rata-rata dan persentase dari setiap variabel penelitian.Data kualitatif merupakan data yang diperoleh dari aktivitas peternak di lapangan sesuai dengan variabel penelitian. Hasan (2004) menyatakan untuk menghitung persentase dari variabel penelitian dapat dilakukan dengan rumus sebagai berikut:

$$
\mathrm{P}=\frac{\mathrm{F}}{\mathrm{N}} x 100 \%
$$

Keterangan :

$\mathrm{P}=$ Persentasi dari hasil indikator penelitian
$\mathrm{F}=$ Frekuensi dari hasil indikator penelitian

$$
\mathrm{N}=\text { Responden }
$$

Karakteristik responden digolongkan berdasarkan pendidikan, usia dan jumlah kepemilikan ternak mengunakan rumus berikut Sarmanu (2006).

$$
\overline{\mathrm{x}} \pm \mathrm{SD} \text {. }
$$

Keterangan :

$$
\begin{aligned}
& \overline{\mathrm{x}} \quad \text { : Rata Rata Populasi } \\
& \text { SD : Standar Deviasi }
\end{aligned}
$$

\section{HASIL DAN PEMBAHASAN}

1. Mata pencaharian masyarakat Kabupaten Sragen

Berdasarkan data Badan Pusat Statistik tahun 2013 dari total jumlah penduduk Kabupaten Sragen sebanyak 891.832 jiwa,yang baru mendapatkan mata pencaharian dengan perkisaran umur 10 tahun ke atas sebanyak 468.120 jiwa, dalam proses pendidikan sebanyak 125.522 jiwa, artinya masih terdapat sebanyak 298.190 jiwa penduduk yang belum mendapatkan mata pencaharian di Kabupaten Sragen. Jumlah penduduk berdasarkan mata pencaharianya dapat dilihatpada Tabel 2.

Tabel 2. Jumlah Penduduk Kabupaten Sragen Berdasarkan Mata Pencaharianya dari Usia10 Tahun ke Atas

\begin{tabular}{llrr}
\hline \hline No & \multicolumn{2}{c}{ Sektor Mata Pencaharian } & \multicolumn{2}{c}{ Jumlah } \\
\hline & & (Iiwa) & (Persen) \\
\hline 1 & Pertanian, Peternakan, Perikanandan Perkebunan & 166.82 & 18,70 \\
2 & Pertambangandan Galian & 4.040 & 0,45 \\
3 & Industri & 66.640 & 7,47 \\
4 & Listrik, Gas dan Air Minum & 324 & 0,36 \\
5 & Konstruksi & 30.300 & 3,40 \\
6 & Perdagangan, RumahMakandanJasaAkomodasi & 111.63 & 12,40 \\
7 & KeuangandanJasaperusahaan & 10.164 & 1,73 \\
8 & Komunikasi & 15.800 & 1,14 \\
9 & Jasakemasyarakatan, SosialdanPerorangan & 60.337 & 6,76 \\
\hline \multicolumn{2}{r}{ Jumlah } & 468.120 & 52,41 \\
\hline
\end{tabular}


Sumber :Data Survey Tenaga Kerja Nasional (SAKERNAS), 2013

Data pada Tabel 5. menunjukkan bahwamasyarakatKabupatenSragenterbesar masih menggantungkan hidupnya pada sektor pertanian, peternakan, perikanandan perkebunan, yaitu sebesar 18,70 persen. Hal ini menunjukkan bahwa sector tersebut harus mendapatkan perhatian khusus dari pemerintah, agar dapat dikembangkan ke arah yang lebih baik, dengan menyediakan kredit modal dan penerapan teknologi tepat guna dengan memanfaatkan potensi daerah.

\section{Pelaksaan Program Agribisnis Peternakan Di Kabupaten Sragen}

Program agribisnis peternakan pedesaan yang dilaksanakan di Kabupaten Sragen, merupakan integrasi dari beberapa program pemerintah pusat, pemerintah provinsi dan lembaga swadaya masyarakat lainya. Program yang diintegrasikan tersebut terdiri dari program pemerintah pusat adalah BLM (Bantuan Langsung Masyarakat) pada tahun 2002 dan program PUAP (Program Usaha Agribisnis Pedesaan) pada tahun 2008, yang merupakan bagian dari program PNPM Mandiri, dari bantuan pemerintah provinsi adalah hibah gubernur, bantuan peternakan pedesaan, sedangkan dari lembaga swadaya masyarakat bantuan pinjaman KUR Bank Jateng dan BRI, bantuan dari Balitbang dan Jamsostek.

Program tersebut terdiri dari beberapa kegiatan di antaranya pengembangan ternak kambing, domba, sapi perah, sapi potong, ayam kampung, ayam ras petelur dan ayam ras pedaging, dengan membentuk kelompok-kelompok ternak di wilayah Kabupaten Sragen, sudah berjalan sejak tahun 2004. Jumlah kelompok ternak yang terhimpun dalam program agribisnis peternakan pedesaan di Kabupaten Sragen pada tahun 2012 yang aktif berjumlah 163 kelompok, terdiri dari kelompok ternak sapi potong 98, kambing 12, domba 43, ayam potong 1 dan ternak itik 9 (Dinas Peternakan dan Perikanan, 2012).Kelompok ternak tersebut tersebar di beberapa kecamatan seperti Masaran, Sidoharjo, Kedawung, Plupuh, Gondang, Sumberlawang, Sambung Macan dan Karang Malang.

Kelompok ternak sapi potong yang terdapat di Kabupaten Sragen, terutama yang terhimpun dalam program agribisnis peternakan pedesaan, mengalami penurunan, pada tahun 2004 tercatat sebanyak 132 kelompok ternak sapi potong namun pada tahun 2013 tinggal 82 kelompok ternak sapi potong, artinya selama 9 tahun program agribisnis peternakan pedesaan di Kabupaten Sragen berjalan mengalami penurunan jumlah kelompok ternak yang dibina oleh dinas Peternakan dan Perikanan Kabupaten Sragen sebanyak 37, $87 \%$. Hal ini di sebabkan karena banyaknya kelompok ternak yang fiktif, terbukti dari hasil observasi lapangan peneliti menemukan 3 kelompok yang fiktif, selain ituterdapat beberapa peternak yang tidak mengembalikan kredit kepada lembaga yang memberikan bantuan modal.

Program agribisnis peternakan pedesaan yang dilaksanakan di Kabupaten Sragen merupakan sebuah sistem manajemen agribisnis yang dilakukan dengan pendekatan kelompok. Menurut Purbayu (2005) dan Krisnamurthi (2010) agribisnis merupakan suatu sistem yang terdiri dari empat komponen masingmasing penyediaan sarana produksi, proses produksi/menghasilkan produk peternakan, pengolahan hasil, dan pemasaran hasil. Keempat subsektor tersebut merupakan upaya untuk memajukan pertanian yang modern menuju kepada ketangguhan 
perekonomian Indonesia, hal ini memerlukan kemauan politis (political will) dari pemerintah untuk mengerahkan segala sumberdaya dan sumber dana yang dapat dimiliki untuk mengembangkan keempat komponen (subsistem) tersebut. Pelaksanaan program tersebut di Kabupaten Sragen berjalan dengan fungsinya masingmasing, namun masih banyak terdapat pelaksanaan dijalankan secara individu oleh peternak sapi potong.

\section{Dampak Program Agribisnis}

\section{Peternakan terhadap Peternan}

Program agribisnis peternakan pedesaan yang dijalankan di Kabupaten Sragen, merupakan salah satu upaya untuk mengurangi tingkat kemiskinan di pedesaan terutama di Kabupaten Sragen. Dampakprogram agribisnis peternakan pedesaan yang sudah dilaksanakan di Kabupaten Sragen dapat dilihat dari dampak terhadap dorongan masyarakat dalam membentuk kelompok ternak, dampak terhadap jumlah kepemilikan ternak sapi potong dan kemampuan peternak mendapatkan bantuan modal.

a. Dampak terhadap pembentukan kelompok ternak sapi potong

Indikator pertama yang dapat dilihat dari dampak program agribisnis peternakan pedesaan terhadap peternak sapi potong di Kabupaten Sragen, adalah tingkat dorongan peternak untuk membentuk kelompok ternak sebagai sarana mendapatkan bantuan. Pembentukkan lembaga kemasyarakatan termasuk kelompok ternak sangat ditentukan oleh faktor pendorongnya, sebagian besar peternak membentuk kelompok ternak berdasarkan faktor yang dapat menguntungkan peternak. Hal ini dapat terbukti dari hasil penelitian terdapat sebanyak 72,55 persen berdirinya kelompok ternak sama dengan waktu peternak mendapatkan bantuan, salanjutnya 27,45 persen peternak membentuk kelompok sebelum mendapatkan bantuan, artinya bahwa sebagian besar peternak membentuk kelompok dipengaruhi oleh kepentingan untuk mendapatkan bantuan melalui program tersebut.

\section{b. Dampak terhadap kepemilikan ternak dan kemampuan peternak mendapatkan bantuan modal.}

Indikator kedua yang dapat dilihat daridampak program agribisnis peternakan pedesaan terhadap peternakadalah peningkatan jumlah kepemilikan ternak dan kemampuan peternak dalam mengakses modal.Hasil penelitian menunjukan Dari 51 responden, bahwa jumlah ternak sapi potong yang dipelihara setelah mendapatkan program agribisnis peternakan pedesaan, mengalami peningkatan dan keberdaayaan peternak mengakses modal mengalami penurunan, lebih jelas dapat dilihat pada Grafik1.

Grafik 1. Dampak program Agribisnis terhadap peternak

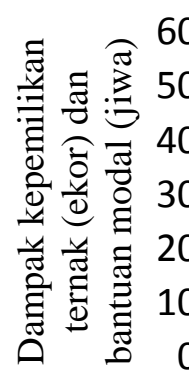

51
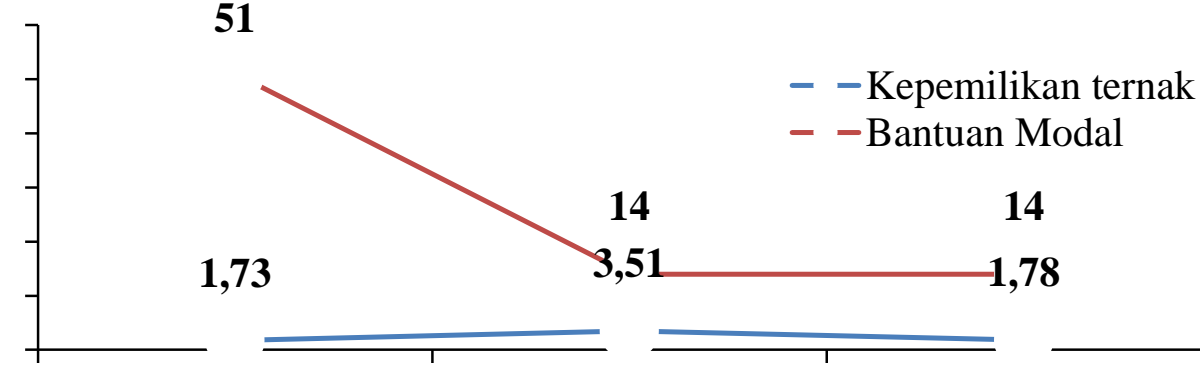

1,73

14

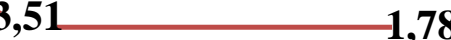

2004

2014

Hasil

Lama Proses (tahun) 
Data pada Grafik 1. dapat dijelaskan bahwa jumlah ternak yang dipelihara peternak, sebelum mendapatkan program atau pada tahun 2014 sebanyak 88 ekor dengan rata-rata kepemilikan 1,73 ekor, setelah mendapatkan program agribisnis peternakan pedesaan jumlah ternak yang dipelihara sebanyak 182 ekor dengan ratarata kepemilikan 3,51 ekor. Jumlah ternak sapi potong yang dipelihara peternak selama mendapatkan program agribisnis peternakan pedesaan meningkat hingga 50,71 persen yaitu sebesar 1,78 ekor dapat dilihat pada (Lampiran 3.). sistem pemeliharaan sapi potong yang terdapat di Kabupaten Sragen yaitu penggemukan dengan membeli pedet dan pemeliharaan dengan membibitkan sendiri. Hasil penelitian menemukan sebanyak 51 persen peternak memelihara ternak sapi potong tujuan penggemukan dengan membeli pedet, dengan lama pemeliharaan 3 bulan sampai 5 bulan, sebanyak 49 persen peternak memelihara ternak sapi potong tujuan penggemukan dengan membibitkan ternak sendiri, dengan lama pemeliharaan 1,5 tahun sampai 2 tahun. Peternakyang memelihara dengan tujuan penggemukkan dengan membeli pedet, selama 2 tahun dapat menjual 4 ekor sampai 6 ekor ternak sapi potong, sedangkan penggemukan dengan membibitkan sendiri, selama 2 tahun dapat menjual 1 ekor sampai 2 ekor sapi potong.

Berdasarkan penjelasan maka dapat diartikan bahwa jumlah ternak sapi potong yang dipelihara peternak saat ini meningkat hingga 50 persen. Menurut Said et al. (2006) peternak dianggap miskin jika jumlah kepemilikan ternak relatif kecil, yaitu rata-rata kepemilikan ternak kurang dari 3 ekor. Kepemilikan ternak sapi potong di Kabupaten Sragen sudah mencapai ratarata 3,51 ekor setiap peternak yang menerima bantuan agribisnis peternakan pedesaan, hal ini menunjukkan program agribisnis peternakan pedesaan, dapat meningkatkan perekonomian masyarakat.

Dampak terhadap kemampuan peternak dalam mendapatkan bantuan modal, mengalami penurunan.Hasil penelitian menunjukkan pada awal program agribisnis yaitu tahun 2004 jumlah peternak yang mendapatkan bantuan 51 peternak, sedangkan pada tahun 2014 jumlah peternak yang mendapatkan bantuan modal lanjutan hanya 14 peternak, artinya kemampuan peternak dalam mendapatkan modal lanjutan menurun hingga 72,55 persen.

\section{Tingkat pemberdayaan peternak}

Menurut Pranarta dan Moeljarto(1996) bahwa pemberdayaan adalah serangkaian kegiatan untuk memperkuat kemampuan kelompok lemah, dalam masyarakat termasuk individu-individu petani/peternak. Pemberdayaanpeternak sapi potong melalui program agribisnis peternakan pedesaan di Kabupaten Sragen, dalam penelitian ini dilihat dari tingkat kemampuan peternak dalam mengakses modal, informasi dan teknologi, selain itu dilihat dari tingkat partisipasi peternak dalam mengambil keputusan dalam kelompok.

\section{a. Tingkat kemampuan peternak dalam mengakses modal}

Permasalahan yang mendasar bagi peternak rakyat di pedesaan adalah kekurangan modal dan rendahnya pengetahuan peternak, terhadap cara untuk mengakses modal, kepada lembagalembaga perbankan dan kemitraan. Suharto dan Edi (2006) menyatakan bahwa salah satu tujuan dari pemberdayaan adalah, memberikan daya atau pengetahuan kepada pihak yang lemah untuk dapat menjangkau sumber-sumber produktif, yang memungkinkan mereka dapat 
meningkatkan pendapatannya dan memperoleh, barang-barang dan jasa-jasa yang mereka perlukan.Pemerintah Kabupaten Sragen melalui program agribisnis peternakan pedesaan yang sudah berjalan sejak tahun 2004, yang dilaksanakan oleh Dinas Peternakan dan Perikanan Kabupaten Sragen, banyak membantu peternak rakyat dalam penyediaan akses terhadap pinjaman modal, baik bersifat pinjaman maupun bantuan langsung.
Hasil penelitian menunjukkan bahwa terdapat beberapa sumber dana yang dapat diakses oleh peternak, diantaranya: Bantuan langsung pemerintah, Bank BRI, Bank Jateng, Balitbang dan Jamsostek. Bantuan dan pinjaman modal yang diberikan oleh lembaga tersebut, harus melalui kelompok ternak, tingkat kemampuan peternak dalam mengakses bantuan daan pinjaman modal dapat dilihat pada Grafik 2.

Grafik 2. Tingkat kemampuan peternak mengakses modal

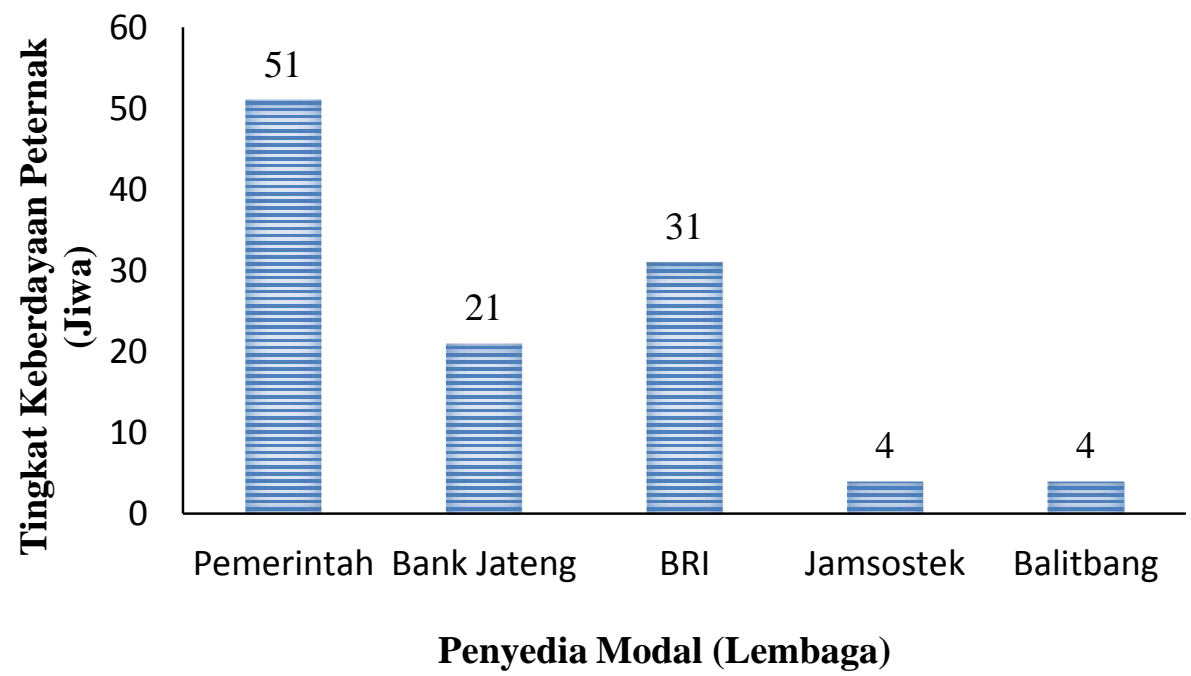

Tingkat kemampuan peternak dalam tersebut, sebanyak 2 peternak atau 3, 92 mengakses modal pada grafik 2. dapat dijelaskan bahwa keseluruhan peternak persen hanya mengakses kepada Balitbang, mengakses bantuan modal kepada pemerintah, terdapat 31 peternak atau 58,82 persen mengakses dari Bank BRI, 21 peternak atau 41,18 persen mengakses modal dari Bank Jateng dan sebanyak 4 peternak atau 7,84 persen mengakses dari Balitbang dan Jamsostek.

Tingkat kemampuan peternak dalam mengakses modal berbeda beda, dimana terdapat 2 peternak atau 3, 92 persen dapat mengakses modal dari kelima sumber Jamsostek dan Pemerintah, selanjutnya 11 peternak atau 21,57 persen mengakses kepada Pemerintah, Bank BRI dan Bank Jateng, terdapat 10 peternak atau 19,11 persen hanya mengakses kepada pemerintah dan Bank Jateng dan 20 peternak atau 39,22 persen hanya mengakses kepada pemerintah dan Bank BRI, lebih jelasnya dapat dilihat pada (Lampiran 4.). Berdasarkan penjelasan di atas maka dapat artikan bahwa baru sebagian kecil peternak dapat mengakses bantuan Modal dari lembaga penyedia 
modal. Kemampuan peternak dalam mengakses modal, ditentukan oleh tingkat aktifitas anggota dan pengurus kelompok ternak dalam mencari akses sumber modal, adanya kemampuan pengurus kelompok ternak dalam membina kelompok dan tingginya tingkat partisipasi peternak dalam kelompok. Hal ini Selaras dengan salah satu tujuan dari program agribisnis pedesaan adalah untuk memperkuat modal usaha kelompok dalam mengembangkan usaha kelompok(Departemen Pertanian, 2009).

\section{b. Tingkat kemampuan peternak dalam mengakses informasi}

Tingkat kemampuan peternak dalam mengakses informasi dapat dinilai dari kemampuan peternak dalam mengakses informasi pasar dan informasi pengunaan obat-obatan ternak sapi potong yang digunakan sehari-hari. Informasi pasar yang diperoleh peternak di tentukan oleh tingkat intensitas dan aktivitas anggota kelompok.Tingkat kemampuan peternak dalam mengakses informasi dapat dilihat pada grafik 3 .

Gambar 3. Tingkat kemampuan peternak mengakses informasi

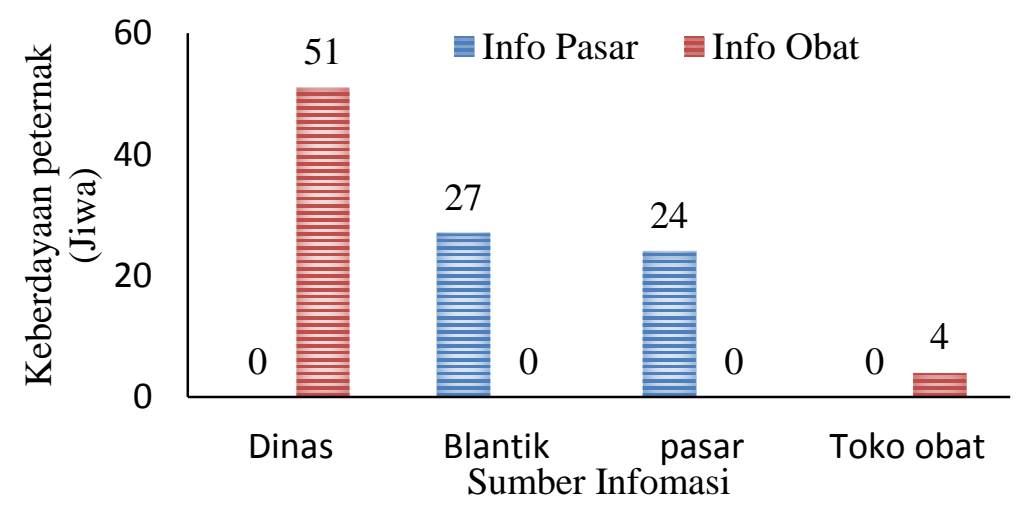

Berdasarkan grafik 3. menunjukkan sebanyak 27 peternak atau 52,94 persen mengakses informasi pasar kepada blantik secara individu dan 24 peternak atau 47,05 persen mengakses informasi pasar ke pasar sapi yang berada di Kabupaten Srangen secara individu, dapat dilihat pada (Lampiran 5.). Informasi pasaryang dapat diakses oleh peternak yaitu blantik dan pasar sapi.Hal ini bertentangan dengan pendapat Suharto dan Edi (2007) bahwa salah satu pengertian pemberdayaan adalah memberikan informasi dan pengetahuan terhadap aktivitas ekonomi kepada masyarakat yang lemah, diantaranya kemampuan memanfaatkan dan mengelola mekanisme produksi, distribusi, dan pertukaran barang dan jasa. Hasil penelitian dapat dilihat bahwa peran dan fungsi pemrintah daerah dalam memberdayakan masyarakatnya dalam hal ini peternak adalah menyampaikan HPP (Harga Pembelian Pemerintah) kepada peternak,maka pemerintah daerah dalam hal ini Dinas Peternakan dan Perikanan Kabupaten Sragen, memiliki peran dalam menyampaikan informasi pasar kepada peternak, namun di Kabupaten Sragen peran tersebut belum dilaksanakan oleh pemerintah.

Rendahnya pengetahuan peternak terhadap jenis dan penggunaan obat dalam proses produksi ternak sapi potong, merupakan salah satu penghambat produktifitas dalam menjalankan usaha ternak sapi potong, sehingga peternak 
membutuhkan informasi tentang jenis dan penggunaan obat. Ilustrasi 4. menjelaskan bahwa terdapat 51 peternak atau 100 persen mengakses informasi tentang jenis dan pengunaan obat dari Dinas Peternakan dan Perikanan Kabupaten Sragen, melalui Petugas Penyuluh Lapangan dan Mantri Hewan secara berkelompok, sedangkan 4 peternak atau 7,84 persen mengakses informasi tambahan dari toko penjual obatobatan ternak sapi potong secara individu, dapat dilihat pada (Lampiran 4.). Informasitambahan yang didapatkan oleh peternak dari penjual obat, di sebabkan karena peternak mencari obat yang diperlukan secara individu, sedangkan peternak yang lain mendapatkan obat secara kelompok, yang disediakan oleh mantri dan penyuluh peternakan.

\section{c. Tingkat kemampuan peternak dalam mengakses teknologi}

Sapja (2004) menyatakan bahwa salah satu contoh dari peternak miskin dilihat dari tingkat keterampilan yang rendah, sehingga jiwa kewirausahaan dan kemampuan manajerial peternak rendah, yang selanjutnya berpengaruh terhadap respon peternak terhadap penerapan teknologi baru lambat, sehingga produktivitas usaha secara keseluruhan rendah. Rendahnya pengetahuan dan kemampuan peternak dalam penerapan teknologi baru, sebagian besar di akibatkan oleh kurangnya lembaga yang dapat diakses oleh peternak, dalam pendapatkan informasi penerapan teknologi terbarukan.Tingkat kemampuan peternak dalam mengakses teknologi dapat dilihat pada grafik 4 .

Grafik 4.Tingkat Kemampuan peternak mengakses teknologi

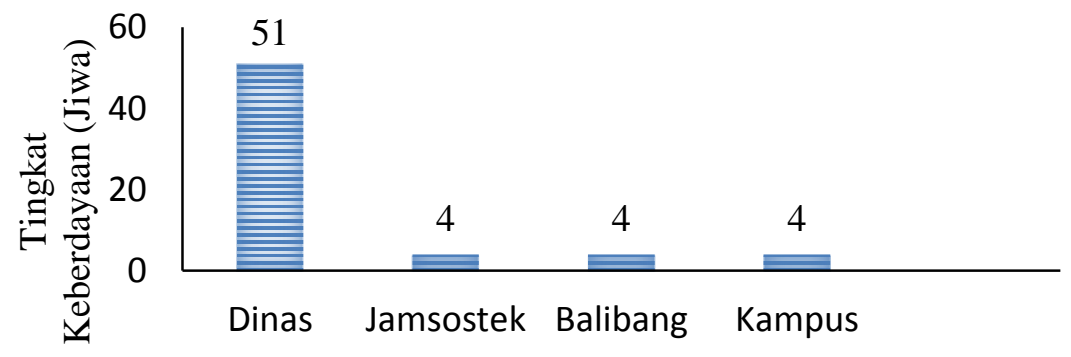

Sumber Teknologi (lembaga)

Berdasarkan grafik 4. dapat dijelaskan bahwa terdapat 51 peternak atau 100 persen mengakses teknologi dari Dinas Peternakan dan Perikanan Kabupaten Sragen, sebanyak 4 peternak atau 7,84 persen mengakses lembaga kemitraan Balitbang, Jamsostek dan Perguruan Tinggi yaitu Universitas Diponegoro, dapat dilihat pada (Lampiran 6.). Peternak yang mengakses teknologi dari kemitraan dan perguruan tinggi adalah peternak yang sama, artinya bahwa peternak masih sedikit mengakses penerapan teknologi dari instansi yang menyediakan pelatihan tentang penerapan teknologi, sedangkan salah satu sasaran yang ingin di capai dari program agribisnis pedesaan adalah meningkatnya proses pembelajaran peternak menjadi lebih mantap, untuk dapat melepas ketergantungannya pada bantuan pemerintah Departemen Pertanian (2009). Lembaga yang mendampingi peternak Dinas Peternakan dan Perikanan Kabupaten Sragen, kemitraan Balibang, Jamsostek dan Fakultas peternakan dan Pertanian Universitas Diponegoro.

\section{Tingkat partisipasi}


Partisipasi merupakan salah satu dilihat dari dua indikator berikut: (1) prinsip dalam pemberdayaan masyarakat Tingkat intensitas pertemuan kelompok pedesaan Pranarta dan Moeljarto (1996), ternak dan (2) Tingkat kebersamaan untuk mengetahui tingkat partisipasi anggota kelompok dalam pelaksaan masyarakat dalam kelompok ternak sapi kegiatan. Tingkat intensitas pertemuan yang potong melalui program agribisnis biasa dilakukan kelompok, dapat dilihat peternakan pedesaan di Kabupaten Sragen, pada Grafik 5.

Grafik 5.Tingkat intensitas pertemuan anggota kelompok ternak

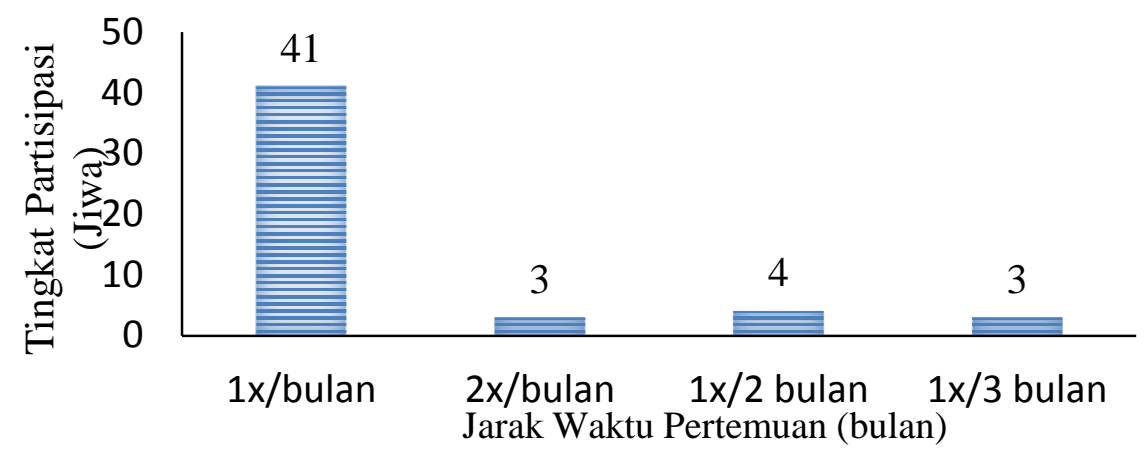

Berdasarkan grafik 5. dapat dijelaskan berkomunikasi untuk mengadakan bahwa indikator tingkat intensitas pertemuan anggota kelompok. Intensitas pertemuan yang dilakukan anggota pertemuan anggota kelompok satu kali kelompok ternak sapi potong di Kabupaten dalam dua dan tiga bulan.

Sragen bervariasi. Perbedaan yang terjadi Indikator kedua adalah tingkat pada intensitas pertemuan anggota kebersamaan anggota kelompok dalam kelompok ternak dipengaruhi oleh melaksanakan kegiatan, yang diukur dari kebersamaan kelompok dalam menjalankan kebersamaan anggota kelompok dalam kegiatan, dimana semua kelompok yang penyediaan pakan, penyediaan obat-obatan menjalankan pertemuan satu kali dan dua dan kebersamaan menjaga keaamanan kali dalam satu bulan, memiliki kandang melalui kandang komunal.Tingkat komunal secara berkelompok, artinya kebersamaan anggota kelompok dalam bahwa dengan adanya kandang komunal, menjalankan kegiatan dapat dilihat pada maka intensitas pertemuaan antar anggota grafik 6.

sering sehingga mudah dalam

Grafik 6. kebersamaan anggota kelompok

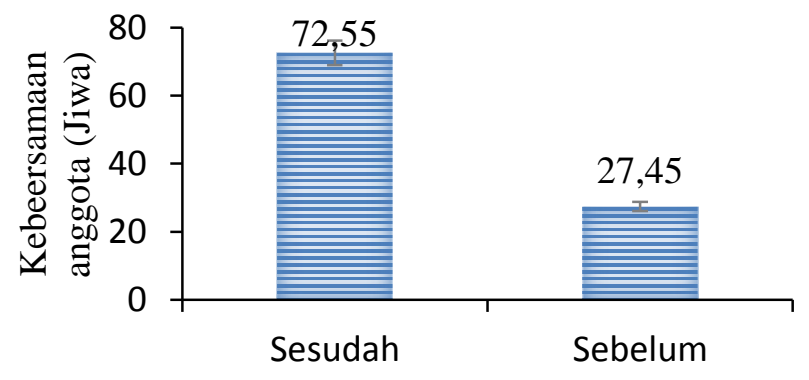

Kondisi kandang 
Berdasarkan grafik 6. dapat dijelaskan bahwa sebanyak 24 peternak atau 47,06 persen, menggunakan kandang komunal secara berkelompok dan 27 peternak atau 52, 94 persen masih menggunakan kandang di rumah secara individu, dapat dilihat pada (Lampiran 7.) artinya bahwa peternak yang memelihara di rumah lebih banyak dibandingkan memelihara di kandang komunal. Penyediaan obat-obatan 100 persen peternak menyediakan secara berkelompok. Penyediaanpakan 100 persen peternak menyediakan secara individu, artinya bahwa peternak yang memelihara di kandang komunal secara kelompok, pemeliharaannya masih dilakukan secara individu.

Pemeliharaan yang dilakukan di kandang komunal secara berkelompok, selain peneyediaan pakan secara individu masih terdapat proses penjualan ternak yang ditentukan secara individu. Hal ini bertentangan dengan pendapat Ekowati et al (2012) menyatakan bahwa dalam menjalankan kegiatan kelompok ternak, membutuhkan kerja sama dari semua anggota, bertujuan untuk mempermudah kegiatan sehingga bisa mencapai tujuan. Tingkat partisipasi anggota kelompok lebih tinggi pada pemeliharaan di kandang komunal di banding dengan kandang rumah, hal ini dilihat dari kegiatan anggota kelompok, anggota kelompok yang memelihara di kandang komunal secara kelompok terdapat piket jaga, seperti yang sudah dibahas pada sub sub bab 4.5.1 sebelumnya.

\section{SIMPULAN DAN SARAN \\ Simpulan}

Berdasarkan hasil penelitian dapat disimpulkan bahwa dampak pelaksanaan program agribisnis peternakan sapi potong secara keseluruhan dapat meningkatkan kemampuan peternak dalam menjalankan usahanya.

\section{DAFTAR PUSTAKA}

Agussabti. 2002. Kemandirian Petani dalam Pengambilan Keputusan Adopsi Inovasi. Pascasarjana Institut Pertanian Bogor. (Disertasi Doktor)

Badan Pusat Statistik. 2013 ${ }^{\text {a }}$ Kabupaten Sragen dalam Angka. Sragen. BPS Kabupaten Sragen

Badan Pusat Statistik. 2013 ${ }^{\mathrm{b}}$. Indonesia dalam Angka. BPS Nasional, Jakarta.

Departemen Pertanian, 2009. Kebijakan Teknis Program Pengembangan Usaha Agribisnis Perdesaan. Departemen Pertanian RI, Jakarta.

Departemen Pertanian, 2008. Kebijakan Teknis Program Pengembangan Usaha Agribisnis Perdesaan. Departemen Pertanian RI, Jakarta.

Departemen Pertanian. 2008. Peraturan Menteri Pertanian No.16/OT.140/2/2008. Departemen Pertanian RI, Jakarta.

Departemen Pertanian, 2007. Kebijakan teknis Bantuan Langsung Masyarakat. Departemen Pertanian RI, Jakarta. 
Dinas Peternakan dan Perikanan. 2011. Laporan Tahunan. Dinas Peternakan dan Perikanan Kabupaten Sragen, Sragen.

Dinas Peternakan dan Perikanan. 2013. Laporan Tahunan. Dinas Peternakan dan Perikanan Kabupaten Sragen, Sragen

Dwidjatmiko, S dan S, Marzuki. 2013. Koperasi Sebagai Wahana Pemberdayaan Peternak. Penerbit Undip Press, Semarang.

Hasan, I. 2004. Analisis Data Penelitian dengan Statistik. Penerbit Bumi Aksara, Jakarta.

Kadarsan, H.W. 1992. Keuangan Pertanian dan Pembiayaan Perusahaan Agribisnis. PT. Gramedia Pustaka Utama, Jakarta.

Krisnamurthi, B. 2010. Pembangunan pertanian: agribisnis, pangan dan kelembagaan: bunga rampai pemikiran Buletin Pusat Studi Pembangunan, Lembaga Penelitian dan Pemberdayaan Masyarakat, Institut Pertanian Bogor, Bogor.

Lala, M Kolopaking dan F, Tonny. 2006. Pengembangan Masyarakat dan Kelembagaan Pembangunan. Lembaga Penelitian Pengabdian Masyarakat, Institut Pertanian Bogor, Bogor.

Menko Kesra, 2008.Pidato pada acara Rapat Kerja Gubernur, Bupati dan Walikota Se Indonesia dalam rangka pemantapan pelaksanaan PNPM Mandiri di daerah, 30 Januari 2008 di Jakarta.

Murtidjo, B.A. 1990. Beternak Sapi potong. Kanisius Yogyakarta.

Nasution dan Muslimin. 2002. Pengembangan Kelembagaan Koperasi Pedesaan untuk Agroindustri, IPB Press, Bogor.(tidak dipublikasikan).

Nugroho dan Dahuri. 2004. Pembangunan Wilayah: Perspektif Ekonomi, Sosial dan Lingkungan. LP3ES,Malang-Bogor.

Pranarka,A,M,W dan V, Moeljarto.1996. Pemberdayaan Masyarakat: Konsep, Kebijakan, dan implementasi. CSIS, Jakarta.

Purbayu, B, S. 2005. Pembangunan sektor pertanian melalui pola agribisnis menuju ketangguhan perekonomian Indonesia. J "Dialogue” JIAKP, 2 : 674-685.

Sirageh, B. 1998 Kumpulan Pemikiran Agribisnis Berbasis Peternakan. Catatan kedua. Pustaka Wirausaha Muda, Bogor.

Sapja, A. 2004. Gambaran Kemiskinan Petani dan Alternatif Pemecahannya. Panduan Mata Kuliah Pengantar Falsafah Sains, Institut Pertanian Bogor, Bogor.

Said, R. E, S, Wahyuni. Melani dan A. Sunito. 2006. Kependudukan. Lembaga Penelitian Pengabdian Masyarakat, Institut Pertanian Bogor, Bogor.

Suharto dan Edi. 2006. Membangun Masyarakat Memberdayakan Rakyat. Kajian Strategis Pembangunan Kesejahteraan Sosial dan Pekerjaan Sosial. PT Refika Aditama, Bandung.

Suharto dan Edi. 2007. Kebijakan Sosial sebagai Kebijakan Publik. Penerbit Alfabeta, Bandung. 
Sumodiningrat, G., B. Santoso dan M. Maiwan. 1999. Kemiskinan: Teori, Fakta dan Kebijakan. Edisi Pertama. Penerbit IMPAC, Jakarta.

Sumarti, T. D, Murtini dan W, Ardi. 2008. Model Pemberdayaan Petani dalam Mewujudkan Desa Mandiri dan Sejahtera (Kajian Kebijakan dan Sosial Ekonomi Tentang Ketahanan Pangan pada Komunitas Desa Rawan Pangan di Jawa). [Laporan Akhir]. Lembaga Penelitian dan Pengabdian Kepada Masyarakat, Institut Pertanian Bogor Press, Bogor.

Syahyuti. 2007. Kebijakan pengembangan gabungan kelompok tani (GAPOKTAN) sebagai kelembagaan ekonomi di perdesaan. Jurnal Analisis Kebijakan Pertanian 1: 15-35.

Sulistiyono.SE.2009. Manajemen Keuangan. http://ilmumanajemen.wordpress. com /2014/01/17/sumber-modal/ (diakses pada tanggal 21 januari 2014).

Sarmanu, 2006. Teknik Sampling \& Penghitungan Besar Sampel. Lembaga Penelitian dan Pengabdian Masyarakat Universitas Airlangga Angkatan IV. Surabaya.

Sihaloho, H. 2004. Pemberdayaan pengusaha kecil di Kabupaten Bogor. Makalah Seminar. Sekolah Pascasarjana. Institut Pertanian Bogor, Bogor.

Ekowati, T. E,Prastyo. D, H, Darwanti. S, Nurtini dan D, Maharso. 2012. Peluang Pengembangan Usaha Ternak Sapi Potong Di Beberapa Daerah Potensi Sapi Potong, Jawa Tengah. (Laporan akhir). Semarang. Lembaga Penelitian Universitas Diponegoro, Semarang.

Van den Ban, A.W dan Hawkins, H.S. 1999. Penyuluhan Pertanian. Penerbit Kanisius, Yogyakarta. (Diterjemahan oleh A.D. Herdiasti)

Yudhoyono, S. B, 2006, Pembangunan Pertanian Indonesia dari Revolusi Hijau ke Pertanian Berkelanjutan, Orasi Ilmiah di Universitas Andalas Padang Tanggal 21 September 2006 http://www.indonesia.go.id. 